\title{
組織能力としての CRM
}

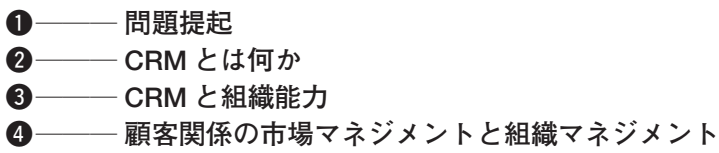

\section{近藤 公彦 \\ 小樽商科大学大学院 商学研究科教授}

\section{1 - 問題提起}

CRM (Customer Relationship Management）は，顧客との長期的な関係構築・維持 を通じて収益を高める手法として IT ベンダー により 1990 年代半ばに提唱され，産業界に急 速に普及してきた。米国 IDC 社によれば, CRM ソルーションの全世界の販売高は 2004 年から 2008 年の間で年間 $8.9 \%$ の成長が見込 まれるという（Raman, Wittmann, and Rauseo 2006)。IDC ジャパンの調査では，日 本の市場規模は 2006 年で 4,413 億円とされ, 2011 年には 5,705 億円に達すると予想されて

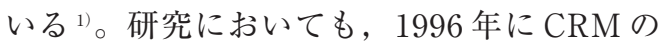
学術専門雑誌 Customer Relationship Managementが発行され，またJournal of Marketing 誌が 2005 年 10 月号で CRM の特集を 組むなど，多くの研究蓄積がなされてきてい る。

しかし，その一方で CRM が必ずしも期待 通りの成果をもたらしていないという現状も 報告されている。例えば，米国 CSO 社による 世界1,337 社を対象とした調査では，CRM の
導入によって大きな業績の改善が見られた企 業は $25 \%$ にすぎいという（Dickie 2005）。 顧客との長期的な関係を構築・維持すること によって競争優位を確立し, 安定的な収益を 獲得しょうとする企業にとって，CRM がそう した経営課題に対する優れたアプローチであ るにもかかわらず，それが必ずしも成功しな いのはなぜか。この論文の目的は，CRM の構 造を分析し，顧客関係を成功裏に管理する際 の組織能力の重要性を明らかにすることにあ る。

以下ではまず，理論研究の視点から CRM の文献レビューを行い，CRM がどのような側 面から捉えられてきたのかを考察する。次に, これまで明確にされてこなかった組織能力と しての CRM を 5 つの次元から分析し, CRM への実践的な行動指針として指摘されてきた 論点に関連づける。最後にCRMにおける 2 つの局面，顧客関係の市場マネジメントと組 織マネジメントを整理する。

\section{2-CRM とは何か}

CRM が実体としてどのような活動を指すの かをめぐっては，これまで多くの議論がなさ れてきた。そのなかで比較的共通した顧客関 
係の理解は次のようなものであろう。企業は, （1）効果的に顧客をセグメント化し，（2）利 益を生む顧客との長期的な関係を構築・維持 し，（3）利益を生まない顧客をいかに扱うか を決定し，（4）市場への提供物と販促努力を カスタマイズしなければならない (Srivastava, Shervani, and Fahey 1999)。ここから明 らかなように，CRM は優良顧客との長期的な 関係の維持・構築に関わり，この点において 伝統的なリレーションシップ・マーケティン グ（relationship marketing）と密接に関連す る「古くて新しい」コンセプトである（Dibb and Meadows 2004)，そこでまず，CRM と リレーションシップ・マーケティングの関連 を整理することにしよう。

\section{CRM とリレーションシップ・マーケティング}

$\mathrm{CRM}$ とリレーションシップ・マーケティン グとの関連で特徴的な点は, 以下の 3 点にま とめられる。第一に, CRMをリレーションシ ップ・マーケティングの派生物として捉える ことである。例えば, Zablah, Bellenger, and Johnston（2004）は，CRM をリレーションシ ップ・マーケティングと思想的に関連した派 生物と見なしている。ここでいう思想的な関 連とは顧客中心主義（customer centricity） の発想である。顧客中心主義のマーケティン グ (customer-centric marketing) とは, 顧 客のニーズやウォンツをマス・カスタマイズ された提供物を通じて個人レベルで充足し, より高い顧客満足を引き出すマーケティング を指す (Shath, et al. 2006; Sheth, Sisodia, and Sharma 2000)。CRM の実践が一方で顧客デ ータに基づいてよりニーズに適合した製品・ サービスを提供することで顧客に価值と満足
を提供し, 他方で満足した顧客がロイヤルテ イを生み，その売り手から継続的に製品・サ ービスを購入することで，売り手に安定的な 利益という価值をもたらす。こうした互恵的 な連鎖は,「価值の二重の創出」(Boulding et al. 2005）として顧客中心主義の思想の中核を なしている。

第二の特徵は，この思想から生まれる具体 的な行動レベルにおいて，CRM をリレーショ ンシップ・マーケティングの実践あるいはそ の適用領域として位置づける点である。例え ば, Peppers, Rogers, and Dorf（1999）は, CRM を顧客情報に基づいて個々に対応するワ ン・トゥ・ワン・マーケティング (one-to-one marketing) やリレーションシップ・マーケ ティングの応用と見なしている。またZeithaml（2001）によれば，CRM は組織全体に わたるリレーションシップ・マーケティング の実践であり，優れた顧客価值，企業との相 互作用の便宜性など関係戦略のベネフィット を企業にもたらす。

第三の特徵は, Ryals and Payne (2001) がCRM を情報によって可能となったリレー ションシップ・マーケティング (informationenabled relationship marketing) と捉えてい るように，行動レベルにおける価値創出を実 現可能にする情報技術に焦点が当てられるこ とである。CRM で用いられる情報技術は CRM テクノロジー (CRM technology) と呼 ばれ，ビジネスや業務プロセスに関わるオペ レーショナル CRM, 顧客データの処理を扱う アナリティカル CRM, そして顧客接点のマネ ジメントに関わるコラボレーティブ CRM か らなる（Greenberg 2001; Payne 2006）。

Payne（2006）は，CRM が情報技術の可能 
性とリレーションシップ・マーケティング戦 略を統合し，利益を生む長期的関係をもたら すとし，データと情報を利用する機会を増や すことで顧客を理解し，リレーションシッ プ・マーケティング戦略をより良く実施する と主張している。ここでは情報技術を通じた 顧客データの収集・分析による顧客行動の定 量的把握が強調されている。また南（2005） は,さきざまな顧客接点から入手できる顧客 情報を蓄積し，活用することにより，顧客と の関係を深耕していくのが CRM という経営 手法である，と述べている。このように顧客 との関係構築・維持において企業と顧客を結 びつける紐帯が情報であり，それを基盤とし て顧客ロイヤルティ・プログラムをはじめと する CRM が実践されるのである。

\section{CRM の定義}

以上のように CRM は，（1）リレーション シップ・マーケティングの思想的派生物，（2） リレーションシップ・マーケティングの実践 あるいはその適用領域，および（3）価值創出 を実現可能にする情報技術，の3つの点から リレーションシップ・マーケティングと密接 に関連する。そこで次に，代表的な研究者に よる CRM の定義に着目し，CRM がどのよう な側面から理解されてきたのかを確認しょう。

Payne and Frow（2005）は, CRMには狭 義の捉え方から広義の捉え方まで，さまざま な見解があることを指摘している。彼らよれ ば CRM は最も狭義には,「特定のテクノロジ ー・ソルーション・プロジェクトの実施に関 するもの」と定義される。ここで CRM は, 情報技術を通じて顧客の問題解決を図る活動 として理解されている。情報技術の適用に焦
点を当てる研究はほかにも, O’Malley and Mitussis (2002) やShoemaker（2001）があ る。例えば, O’Malley and Mitussis (2002) は, 成功する顧客関係を発展させるための能 力は, 組織がその顧客, 個々の好み, 期待, ニーズの変化を理解する能力に依存しており, その理解に情報技術は決定的な役割を果たす ことを強調している。

Payne and Frow（2005）が示す CRM の広 がりはさらに，「統合された一連の顧客志向の テクノロジー・ソルーションの実施」という 情報技術による顧客の問題解決活動を指す中 間的な捉え方を経て，最も広義には「株主価 值の創出を目的に顧客関係を管理するための 全体的なアプローチ」と位置づけられる。こ こでは優良顧客との長期的な関係の維持・構 築により競争優位を高め, 株主価值に貢献す るという CRM の役割が指摘されている。

このように CRM は，顧客関係を構築・維 持する手段としての情報技術に焦点を当てる ものから，株主価值の向上のための全体的な 顧客関係行動として理解するものまで広がり を持つ。CRM の多義性は研究者のさまざまな 問題意識に依存するものであり，それぞれの 定義は相互排他的ではなく，また収斂させる べき性質のものではない。それゆえ，CRMを 理解するための生産的な方法は，そうした多 義性を認めたうえで重要な側面を浮かび上が らせることである。

このアプローチで CRM の定義を考察する と, 次のような 3 つ側面が明らかとなる。 すなわち, プロセスとしての CRM, 戦略とし ての CRM，そしてこれらを合わせ持つプロセ ス・戦略としての CRM である（図ー1参照）。 
口図-1

CRM の定義

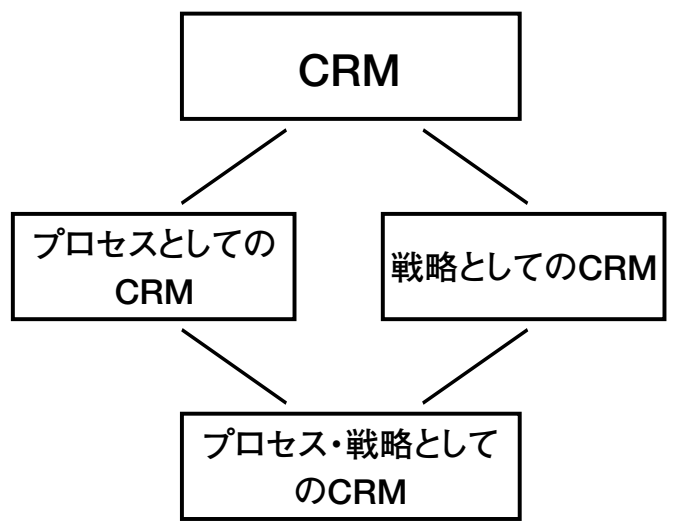

(1) プロセスとしての CRM

CRM の第一の側面は，そのプロセスに注目 した定義である。Reinartz, Krafft, and Hoyer （2004）によれば，CRM とは「顧客とのあら ゆるコンタクト・ポイントにわたって顧客関 係の開始，維持，解消を管理し，関係ポート フォリオの価值を最大化するための体系的プ ロセスである」と定義され，顧客関係の管理 プロセスであることが強調される。管理とい う点では，Hobby （1999）も同様に，「顧客 との関係を管理することによって組織が彼ら を識別し，引き付け，利益の上がる顧客の維 持を向上させる管理アプローチ」と捉えてい る。また Srivastava, Shervani, and Fahley （1999）は，CRM を「顧客を識別し，顧客知 識を創造し，顧客関係を構築し，そして組織 とその製品（問題解決）に関する顧客の認知 を形成するプロセスである」と位置づけ， $\mathrm{CRM}$ プロセスとともに中核的なビジネス・プ ロセスとして，顧客のニーズやウォンッの問 題を解決する製品開発プロセス，およびあら ゆる物的インプットの獲得とそのインプット が顧客の問題解決に変換される効率と効果を
含むサプライ・チェーン・マネジメント・プ ロセスを取り上げている。

Day and Van den Bulte (2002) は，「顧客 維持とマーケティング・イニシアティブの効 果を増大させるために, 最も価值のある顧客 を個別的に扱い，あらゆるコンタクトとアク セス・ポイントにわたって顧客と継続的な対 話を達成するためのクロス・ファンクショナ ルなプロセスである」と述べ， CRM を経営諸 機能を横断するプロセスとして捉えている。 このクロス・ファンクショナルなプロセスと いう視点はKnox et al.（2003）でも指摘され， そこでは「情報技術とリレーションシップ・ マーケティング戦略を統合することによって 顧客価值を促進することを目的としたクロ ス・ファンクショナルなプロセスである」と 理解される。

Zablah, Bellenger, and Johnston（2004）は, CRM を「利益を最大化する顧客関係のポート フォリオを構築・維持するための市場情報の 開発と利用を含む継続的プロセスである」と 捉え，顧客・市場情報に焦点を当てている。 さらにマーケティングの標準的な教科書 Principles of Marketing の著者である Kotler and Armstrong（2007）によれば，CRMは「優 れた顧客価值と満足を提供することによって 利益を生む顧客関係を構築・維持する全体的 なプロセスである」と定義される。

これらの定義に共通する視点は，CRM を顧 客関係の構築・維持に関わる管理プロセスと 位置づけていることである。この管理的側面 からの CRM プロセスの具体的な内容につい て Reinartz, Krafft, and Hoyer（2004）は，上 述のように顧客との関係開始（relationship initiation), 関係維持 (relationship mainte- 
nance)，および関係解消 (relationship termination）の 3 つの連続的なプロセスを提示し ている。この一連のプロセスを組織外部の顧 客との関係に関わることから，顧客関係プロ セスと呼ぶことにしょう。一方, Payne and Frow（2005）によるCRM プロセスでは，戦 略開発プロセス，価值創出プロセス，マル チ・チャネル統合プロセス, 情報管理プロセ ス，および成果の評価プロセスの 5 つのプロ セスが指摘されている。これらのプロセスは CRM における組織内部の機能レベルのプロセ スに注目したものであり, 組織プロセスと呼 ぶことができる。

このようにプロセスとしての CRM は，組 織外部に存在する顧客との境界局面における 関係の維持・構築に関わる顧客関係プロセス と組織内部でそのプロセスを効果的・効率的 に作動させるための組織プロセスの 2 つの側 面を持つ。

(2) 戦略としての CRM

CRM の第二の視点は, 戦略としての CRM である。例えば, Zikmund, McLeod, and Gilbert （2003）はCRM を次のように定義し ている。「CRM はあらゆるプロセスと顧客と のインタラクションが相互にベネフィットを もたらす関係を維持・拡大するのに役立つよ う，情報技術を用いて，包括的で，信頼でき， そして統合的な顧客ベースの視点を企業に提 供するビジネス戦略である」。ここでは顧客べ 一スの視点に注目され，それに立脚した顧客 戦略に焦点が当てられている。またPayne (2006) や Payne and Frow（2005）によれば, CRM とは「主要な顧客と顧客セグメントとの 適切な関係を構築・発展させることにより， 高い株主価值を創出する戦略的アプローチで
ある」。これは株主価值の向上が CRM による 顧客関係の構築・維持によって達成されると いう理解であり，CRM の戦略的重要性を示唆 する定義である。

また Buttle（2004）は CRM を「ターゲッ 卜顧客に利益を上げて価值を創造し提供する ために，組織内のプロセスと機能を外部のネ ットワークを統合する中核的なビジネス戦略 であり，それは高い品質の顧客デー夕を基礎 とし，情報技術によって可能となる」と捉え， 前述の顧客関係プロセスと組織プロセスを連 結する戦略として理解している。さらに南 （2006）は，「企業と顧客に優れた価值を創り 出すために, 選別された顧客を獲得・維持し, パートナー化する包括的な戦略である」と定 義し，CRM を価值創造のための顧客戦略とし て位置づけている。

これらの定義から，顧客関係の構築・維持 を図る組織的な戦略という CRM の側面が浮 かび上がる。Ryals（2005）はこのような顧客 戦略を顧客関係戦略 (customer relationship strategy）と呼び，その具体的な活動として， 選択的顧客獲得, 選択的顧客維持, 資源配分 とサービス・レベル，価格設定，製品戦略， および選択的顧客投資を指摘している。

（3）プロセス・戦略としての CRM

こうしたプロセスと戦略はいずれも CRM において不可欠な側面であり，対立する捉え 方ではない。むしろ，プロセスが CRM の組 織内での管理プロセスにより焦点を当てるの に対し, 戦略は組織外の顧客関係行動に注目 するものと位置づけることができるだろう。 Parvatiyar and Sheth (2001) はCRMがこれ ら 2 つの側面を合わせ持つという理解から， 次のように定義している。「CRMは，企業と 
顧客にとって優れた価值を創造するために, 選別された顧客を獲得し, 維持し, 彼らとパ ートナーを組む包括的な戦略でありプロセス である。CRM は, マーケティング, 販売, 顧 客サービス, サプライ・チェーンの組織の諸 機能の統合を含み，顧客価值を提供する際に より大きな効率と効果を発揮する」。ここでの CRM は顧客戦略であり，それを実行するため のプロセスである。南（2006）も CRMのこ うした側面に着目し，顧客接点から得られた 情報を電子化し，企業内で情報を共有するた めの仕組みづくりである顧客のインターフェ イス戦略と, 収集・蓄積された顧客情報をデ ータ・マイニングなどの手法を通じて分析し， ナレッジと呼ばれる顧客に関する知識や知見 へと変換し，マーケティングの意思決定に生 かそうとする仕組みである顧客ナレッジ分析 戦略の 2 つを指摘している。

以上の CRM の定義をめぐる文献レビュー から明らかなように, CRM は企業に利益をも たらす顧客との長期的な関係構築・維持を担 う顧客関係戦略と, そうした戦略を組織的に 創出・支援する組織管理プロセスの 2 つの側 面に焦点が当てられてきた。

\section{3-CRM と組織能力}

$\mathrm{CRM}$ がプロセスと戦略の 2 つの側面を持つ ことを前提とすると, CRM と経営成果は, 「優れた顧客関係戦略を実施し, 優れた組織プ ロセスで管理すれば，より高い経営成果が得 られる」という因果関係で結ばれる。CRMに 関するこれまでの実証研究は，基本的にこう した関係をめぐって行われてきた（e.g. Mithas, Krishnan, and Fornell 2005; Ryals
2005; Srinivasan and Moorman 2005; Verhoef 2003）。しかし，冒頭に述べたようにCRMを 導入した企業が必ずしも成功を収めておらず， むしろ比率的には失敗した企業の方が多いと いう事実は，CRM の実践の困難さを示唆して いる。

CRM をリレーションシップ・マーケティン グの思想的かつ実践的な適用領域であると捉 えると，CRM をめぐるこうした問題の背景に は, 優れた顧客関係戦略を実施するだけでな く，それを優れた組織プロセスで管理する組 織能力が重要な役割を果たしていることがわ かる。

\section{1. 競争優位の源泉としての組織能力}

組織能力（organizational capabilities）は 一般に, 顧客に価值を提供するために知識や スキル, ビジネス・プロセス, 組織学習を統 合することによって資源を展開する能力を指 L (Day 1994; Grant 1996; Mahoney and Pandian 1992), 企業の長期的な競争優位の源 泉として位置づけられてきた（e.g. Day 1994， 2000, 2003)。組織能力の研究に精力的に取り 組んできたDay は, 組織能力を 3 つのプロセ スに整理している（Day 1994）。

第一は, 組織の外部に焦点を当てたアウト サイド・イン・プロセスであり, 市場センシ ング (market sensing), 顧客連結 (customer linking), チャネル結合 (channel bonding)，および技術モニタリング（technology monitoring) の4つを要素とする。第 二が，組織内部に注目したインサイド・アウ ト・プロセスであり, 財務管理, コスト・コ ントロール, 技術開発, 統合ロジスティクス, 生産・変換プロセス, 人的資源管理, および 
環境の健全さと安全の 6つである。そしてこ れらアウトサイド・イン・プロセスとインサ イド・アウト・プロセスを結びつける連結プ ロセスとして, 顧客注文のフルフィルメント, 価格設定，購買，顧客サービス・デリバリー， 新製品・サービス開発，そして戦略開発の 6 つの要素を指摘する。これらの能力のうち, 競争優位を規定する最も重要な能力として, Day はとくに市場センシングと顧客連結の 2 つを取り上げ，市場に向けて遂行される組織 能力の重要性を強調する。

Day（2000）はさらに企業の市場行動に焦 点を当てた市場関連能力 (market-related capabilities）に注目し，関係志向（relationship orientation), 知識とスキル (knowledge and skill)，およびプロセスの統合と調整 (integration and alignment of process) とい う3つの要素を指摘する。関係志向は組織の マインド・セット，価值，規範のあらゆる部 分に広がり, 製品・サービスの販売前, 販売 中，そして販売後における顧客とのすべての 相互作用に影響を与える。知識とスキルは従 業員の蓄積された経験，データベースと取引 ファイル，およびマネジメント・システムと ルーティンなどの要素からなる。プロセスの 統合と調整は企業間，企業内で機能間の境界 を連結したり，企業をその顧客と結びつける プロセスに関わる。

このように組織能力は顧客との関係構築 · 維持に関連する能力，顧客・市場情報を処理 する能力，そしてそうした活動を組織として 発揮させる能力からなると考えることができ る。

\section{CRM における組織能力の次元}

Day が指摘した市場関連能力が CRM と密 接に関連していることは明らかである。むし ろ，こうした能力は $\mathrm{CRM}$ において遂行され るものであり，CRM は顧客関係に関わる組織 能力そのものであるといえる。以下では，組 織能力としての CRM を CRM 能力と呼ぼう。

Plakoyiannaki and Tzokas (2002) は CRM 能力として, 学習・市場志向能力 (learning and market orientation capabilities), 分析能 力 (analytical capabilities), オペレーション 能力 (operational capabilities), 統合能力 (integration capabilities), および方向づけ能 力 (direction capabilities) という5つの次元 を指摘している。これらの能力をDay（2003） の市場関連能力の要素に対応づければ, 関係 志向は学習・市場志向能力と方向づけ能力に, 知識とスキルは分析能力とオペレーション能 力に，そしてプロセスの統合と調整は統合能 力に，それぞれ結びつけることができる。 Plakoyiannaki and Tzokas (2002) はこれら の能力を媣く議論しているわけではないが, ここではその類型を援用しながら CRM 能力 を考察していこう。

(1) 方向づけ能力

方向づけ能力は, 組織と CRM システムが 進むべき方向性を示す役割を担うものであり， 企業の長期的なビジョンや組織価值を反映し, 組織の戦略的スキルに依存する（Plakoyiannaki and Tzokas 2002)。

どのような方向づけに基づいて CRM を実 践するかは，次の 2 つレベルで捉えること ができる。第一は，CRM の顧客中心マーケテ イングに関係し，Kohli and Jaworski（1990） が市場志向の成果として指摘する要素に対応 
する。すなわち, 組織の戦略フォーカスや明 確なビジョン, 従業員に対する心理的・社会 的なべネフィット, 顧客の態度や行動の変化 といった市場志向の成果を CRM を通じて実 現することである。ここでCRM は，市場志 向という方向づけのもとでその成果を実現す る手段として位置づけられる。第二に，多く の研究者が指摘するように, CRM は顧客に対 する戦術・戦略以上のものであり, 長期的な 関係の構築を通じて「二重の価值創造」 (Boulding et al. 2005) という相互利益的な関 係を創出する仕組みとして捉えられる。

こうした方向づけは単にCRM の実践だけ でなく，それを支える長期的なビジョンや組 織価值の点からもきわめて重要である。CRM が顧客中心マーケティングを標榜し，「二重の 価值創造」を追求するのは, リレーションシ ップ・マーケティングの適用領域として発展 してきたことと密接に関連している。リレー ションシップ・マーケティングでは, 顧客と の長期的な関係の構築・維持を図るために顧 客に対するマーケティングのみならず, 組織 内部のインターナル・マーケティングを通じ て従業員などの人的資源とその能力を調整し, また組織構造を顧客戦略に整合的に編成して いくことが求められる（Barnes 2004）。それ ゆえ，CRMの実践には顧客関係の管理にとど まらず，組織全体にわたる関与が必要とされ るのである。

こうした視点の転換はさらに，「関係」概念 をべースにして構築されるリレーションシッ プ・マーケティングを「取引」に焦点を当て てきた従来のマーケティングからのパラダイ ム・シフトとして捉えることにも関わる（e.g. Dodge 1997; Grönroos 1994; Sheth and Par- vatiyar 1995b)。パラダイム・シフトとして のリレーションシップ・マーケティングの実 践領域である CRM を有効に機能させるには, 組織に埋め込まれた価值, 規範, 行動様式と いった組織文化そのものを管理する能力が不 可欠である。

（2）学習・市場志向能力

CRM における学習・市場志向能力は全体と して, 知識の獲得, 知識の共有, および知識 の記憶・活用・制度化という組織学習のプロ セスに従っている（Crossan et al. 1999; Huber 1991; Miner and Mezias 1996; Nevis et al. 1995）。顧客・市場に関する情報を収集し, 顧客のプロフィールや行動を学習することに より，顧客に関する梁い知識や洞察，すなわ ちカスタマー・インサイト (customer insight）を獲得することができる。このカス タマー・インサイトは組織全体で共有され, 解釈され, 活用されなければならない。なぜ なら, 顧客サービスの改善, 革新的な製品開 発, コストを削減する生産, そして優れた品 質管理はカスタマー・インサイトに基づいて 可能となるからである (Plakoyiannaki and Tzokas 2002)。組織は, このカスタマー・イ ンサイトを追求することにより顧客価值 (customer value) を創造する。このように組 織の学習は市場に関する学習であり, それは 外部環境と組織との相互作用を生み出す市場 志向を含む（南 2006）。

Srinivasan and Moorman（2005）は実証分 析に際して, Kohli and Jawarski (1990) の 市場志向の 3 つの要素である情報の創造, 情 報の普及，および情報への反応性を $\mathrm{CRM}$ 能 力として援用している。この視点は， CRM 能 力が市場志向の要素から構成されること, す 
なわち CRM 能力が市場志向そのものである と捉えていることを示している。

また Raman, Wittmann, and Rauseo（2006） はCRM に扮ける組織学習の要素として, チ ーム志向 (team orientation), システム志向 (system orientation), 学習志向 (learning organization), および記憶志向 (memory orientation）という 4 つの志向を挙げている。 チーム志向は真の学習の基礎であり, ビジョ ンと方向性を共有するプロセスである。また システム志向は，組織全体の学習を統合する 誘因として役立ち，アクションの結果が組織 に対してどのような影響を及ぼすかをすべて の参加者が分析することを要求する。学習志 向を通じて組織は継続的に環境を理解し，新 しいスキルと情報を学習し, 新しい知識を利 用する。そして記憶志向では, 活動から学習 した教訓を継続的にレビューすることで新し い知識を開発する。

顧客情報を収集・共有・解釈し，顧客関係 の継続的な改善を図るという一連の行動は, CRM における最も基本的なプロセスであり， 組織の学習・市場志向は顧客情報に基づく CRM によってはじめて具体性を持つ。組織が CRM を通じて学習・市場志向を実践するとす れば，それに向けて優れた資源とスキルを活 用することは CRM 能力にほかならない。

(3) 統合能力

CRM における統合は 2 つのレベルで捉える ことができる。第一は，CRM で用いられるマ ーケティング・チャネル間の統合である。こ こでの統合能力の焦点は, 最適なマーケティ ング・チャネルの組み合わせを決定し，それ らのチャネル間で好ましい顧客経験を確保し， そして顧客に関する統合的な見方を生み出す
ことにある (Payne 2006; Payne and Frow 2005; Plakoyiannaki and Tzokas 2002)。営業 員, 店舗, 電話, ダイレクト・マーケティン グ, e コマース, 携带電話等による $\mathrm{m}$ コマー ス（m-commerce）など，顧客はさまざまな チャネルを通して売り手と接触する。Payne （2006）はこうした複数のチャネルを統合的に 管理する様式をマルチ・チャネル統合プロセ スと呼んでいる。ここで重要な点は, 顧客関 係においてこれらの異なったチャネルとチャ ネル参加者をどのように組み合わせ，説得的 なコンタクト・ポイントを設定し, 最も効果 的なチャネル・ミックスを達成するかである。 その際の判断基準となるのが最大の顧客価值 の提供，すなわち，どのようなチャネル・ミ ックスが顧客にとって最も大きな価值を提供 することができるのかである。

しかし, 最大の顧客価值の提供という点に 関して，チャネル・ミックスを最適化するだ けでは十分ではない。なぜなら，顧客価值の 最大化は単にマーケティング機能だけでなく, 組織全体にわたるより広範な経営諸機能の統 合を必要とするからである。これが第二の統 合のレベルである。こうした認識は多くの CRM 研究者において共有されている。例えば, Day（2000）は，市場関連能力の決定的な特 徵は, 企業間の境界, 企業内の機能の境界, 顧客と企業との境界を連結するプロセスであ るとし，CRM の機能の統合とそれに伴う組織 構造の配置を市場関連能力として挙げている。 Parvatiyar and Sheth (2001) は, マーケテ イング, セールスと顧客サービス, 組織のサ プライ・チェーン機能の統合を取り上げ, Boulding（2005）は，CRM をマーケティン グ・アイデア，新しく入手可能となったデー 
夕，技術，組織形態の継続的な進化と統合の 結果であると指摘し, 効果的な CRM にはチ ヤネル，技術，顧客，従業員の統合が必要で あると述べている。

南 (2006) は, データ・ウェアハウスを基礎 とする CRM においてサプライ・チェーン・ マネジメントとマーケティングの統合の重要 性を指摘し, Payne（2006）も同様に, CRM には情報，技術，アプリケーションによって 可能となる従業員, オペレーション, プロセ ス，およびマーケティングのクロス・ファン クショナルな統合が必要であると述べている。

こうしたクロス・ファンクショナルなプロ セスや統合という CRM の理解は, マーケテ イング・チャネルに関してだけでなく, 顧客 に優れた価值を提供することに焦点を当てた 組織的な取り組みを必要とする（Day and Van den Bulte 2002; Knox et al. 2003; Payne 2006; Ryals and Knox 2001)。組織的な取り組 みとは，CRM を遂行するためのクロス・ファ ンクショナルな資源配分とそれを可能にする 能力の開発である。こうして顧客価值を最大 化するマーケティング・チャネルを調整・統 合し, 必要な経営資源・スキルを組織内に最 適に配分する能力が $\mathrm{CRM}$ の成否を決定づけ ることになる。

(4) オペレーション能力

CRM におけるオペレーションは CRM 実施 (CRM implementation) に対応づけられ，そ の能力には顧客関係の構築・維持に関わる局 面と，それを組織的に支援する局面がある。

Yim, Anderson, and Swaminathan (2005) は, CRM 実施の要素として, 主要顧客への焦 点, CRM 中心の組織化，知識の管理，および CRM ベース技術の包含の 4 つを挙げている。
第一に, 主要顧客に焦点を当てた組織構造, 組織文化，経営政策，そして報酬システムは CRM の成功に不可欠であり，これらは顧客に 最大の価值を提供するために組織全体に浸透 させなければならない。第二に，CRM 中心の 組織化においては組織構造は硬直的であって はならず，必要な場合には組織を再構築して 顧客価值を創出し，また顧客に焦点を当てた クロス・ファンクショナルなチームの調整を 図らなければならない。第三に，知識の管理 では顧客情報を顧客知識やマーケティング情 報に変換し, 組織全体で共有しなければなら ない。そしてデータベース・マーケティング, データ・ウェアハウジング, データ・マイニン グ等の情報技術を CRM で活用し，利益の上 がる長期的な顧客関係を構築しなければなら ない。Payne and Frow（2005）はCRM実施 のための組織化に関して，CRM 準備評価 (CRM readiness assessment), CRM 変革マネ ジメント (CRM change management), CRM プロジェクト・マネジメント (CRM project management), および従業員参画 (employee engagement）の重要性を指摘している。

一方，南（2006）は CRM 実施をより情報 技術に基づいた活動として捉え，デー夕統合 を含めたデータ・ウェアハウスに関する活動, アナリテイカル CRM, および顧客データの戦 略的利用から構成されるものとして概念化し ている。データウェア・ハウスでは顧客デー 夕の個人レベルの管理，その部門内での共有, そして部門間にわたる共有が行われ，アナリ ティカル CRM では, 購買データの分析, デ ータ・マイニングの実施, データの仮説・検 証が実施され, 戦略的顧客データ利用ではデ ー夕の経営戦略への利用が推進される。 
$\mathrm{CRM}$ 実施としてのオペレーションは， $\mathrm{CRM}$ の捉え方によって顧客関係をめぐる情報 技術を基盤とした戦術レベルから，組織全体 の戦略レベルまで多様である。しかしここで 重要なことは，CRM をどの程度の広がりで捉 えるにせよ，そのオペレーションを実行する 組織能力がきわめて大きな役割を担っている ことである。すなわち，CRM を効果的かつ効 率的に実施するためには，顧客関係に関わる 戦術・戦略に焦点を当てるだけでなく，それ を実行可能にする優れた組織能力を構築する ことが必要とされるのである。

（5）分析能力

CRM を通じて収集された顧客情報は，組織 に扮いて分析・解釈され，マーケティング情 報に変換されなければならない。このプロセ スでは，顧客情報の収集・分析のツールとな る CRM テクノロジーとそれをマーケティン グ情報という実践的な知識に変換する能力が 重要となる。CRM テクノロジーは，顧客関係 の開始・維持・解消という一連のプロセスを 管理するために用いられる情報技術であり， この技術が高度であればあるほど，高い CRM の成果を生み出すことになる (Payne and Frow 2005)。

CRM で行われる分析には, 市場細分化分析, アフィニティ・グルーピング, チャーン・マ ネジメント，顧客プロファイリング，収益性 分析などがある（Payne 2006）。市場細分化 分析では顧客属性に基づいて複数の市場セグ メントに細分化され，アフィニティ・グルー ピング (affinity grouping) により同時購入 される傾向のある関連商品が識別される。ま たチャーン・マネジメント (churn management）でブランド・スイッチを頻繁に行う
「移り気な」顧客が管理され，顧客プロファイ リングから顧客ニーズ，行動，収益性に基づ いてモデルが構築され，顧客行動の予測に用 いられる。そして収益性分析によって顧客生 涯価值 (customer lifetime value) が評価さ れ，個客レベルの収益性が測定・管理される。 こうした一連の分析を通じて，企業は顧客関 係から最大利益をもたらす市場セグメントを 識別し，そこへのマーケティング投資を集中 的に行うことができる (Grant and Schlesinger 1995; Sheth and Parvatiyar 1995a; Sisodia and Wolfe 2000)。

ここでもまた強調しなければならないのは, CRM テクノロジーを駆使した分析プロセスそ れ自体ではなく，この分析プロセスを円滑に 進め，分析結果をマーケティング情報へと変 換する能力の重要性である。高度な CRM テ クノロジーによって顧客分析はかなりの程度 自動化され，一定の結果を導き出すことがで きる。しかし，どのような仮説を持って分析 し，分析結果をどのように解釈し，どのよう

口図-2

CRM 能力とプロセス・戦略

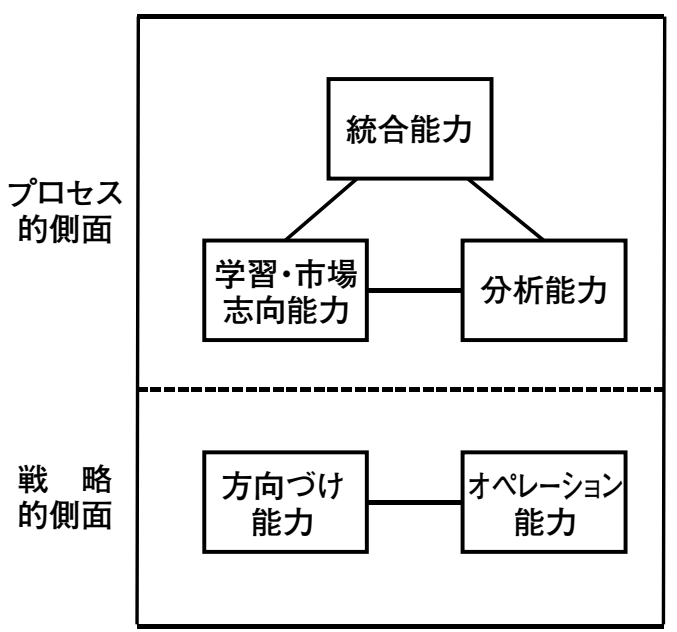


なマーケティング情報に変換し，そしてどの ように CRM 戦略に反映するかは， CRM 能力 に委ねられる。この分析能力は, 定量的な顧 客情報やデー夕から顧客像を立体的に読み取 り，カスタマー・インサイトを浮き彫りにし， 魅力的な市場セグメントを識別し，そしてそ の成果を評価するという一連の知識やスキル からなる。CRM が高い経営成果をもたらすに は，顧客関係のインターフェイスを洞察する 高い分析能力が必要とされるのである。

\section{3. $\mathrm{CRM}$ 能力への 2 つの視点}

$\mathrm{CRM}$ 能力の類型は, 次の 2 点からこれまで の議論に重要な視点を提供する。第一に, CRM における戦略とプロセスという 2 つの側
面を $\mathrm{CRM}$ 能力から構造化することができる (図一 2 参照)。学習・市場志向能力, 統合能力, および分析能力は組織のビジネス・プロセスに おいて発揮されるものであり, 組織を学習・市 場志向に導き，顧客情報を分析し，経営機能や マーケティング・チャネルを統合する際に遂行 される。方向づけ能力とオペレーション能力は 市場における戦略局面に関連しており，CRM を通じて組織が進むべき方向を設定し，それを 実現する組織に変革し，顧客との関係構築・維 持を図る行動において遂行される。

第二に，これまで多くの研究者が指摘してき た CRM の成功・失敗要因を組織能力の視点か ら整理することができる（表－1参照）。方向 づけ能力では，CRMによって顧客と企業のど

口表——1

CRM の成功・失敗要因と組織能力

\begin{tabular}{|c|c|c|c|c|c|c|c|c|c|}
\hline 能力 & $\begin{array}{l}\text { Boulding et al. } \\
\text { (2004) }\end{array}$ & Day (2000) & \begin{tabular}{|l|} 
Dibb and Meadow \\
$(2004)$
\end{tabular} & Kale (2004) & Davids (1999) & $\mid \begin{array}{l}\text { Rigby, Reichheld, } \\
\text { and Schefter (2002) }\end{array}$ & $\begin{array}{l}\text { Raman, Wittmann, } \\
\text { and Rauso (2006) }\end{array}$ & $\begin{array}{l}\text { Ryals and Payne } \\
\text { (2001) }\end{array}$ & $\begin{array}{l}\text { Zablah, Bellenger, } \\
\text { and Johnston (2004) }\end{array}$ \\
\hline 方向づけ能力 & 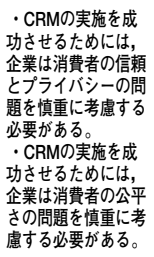 & & $\begin{array}{l}\text { 顧客ベースおよび } \\
\text { 報を管理するため } \\
\text { の技術疽源についで, } \\
\text { 企業の理解が不十分 } \\
\text { である。 }\end{array}$ & $\begin{array}{l}\text { ·経嫦陣の支持か5 } \\
\text { ない。 } \\
\text { ·変革マネジメン } \\
\text { トを過小伍する }\end{array}$ & $\begin{array}{l}\text { ・CRMがどのよう } \\
\text { に自社のためになな } \\
\text { かを問題にしない。 } \\
\text { 自社の戦略を第一 } \\
\text { におかない。 }\end{array}$ & & & \begin{tabular}{|} 
·不十分な投資 \\
・ベネフィット \\
が理解できない。
\end{tabular} & 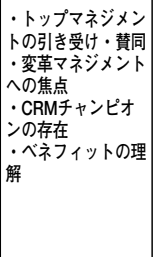 \\
\hline $\begin{array}{l}\text { 学習·市場 } \\
\text { 志向能力 }\end{array}$ & 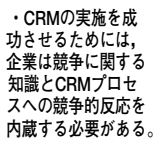 & $\begin{array}{l}\text { 䫘晏と直接接する } \\
\text { 組織が存在しいい。 }\end{array}$ & & 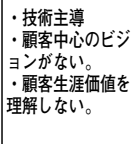 & $\begin{array}{l}\text { •CRMがどのよう } \\
\text { に顧客のためになる } \\
\text { かを問題にしない。 }\end{array}$ & $\begin{array}{l}\text { ·顧客に求愛するの } \\
\text { でななく, つけまわ } \\
\text { す。 }\end{array}$ & & & ·碩客志向 \\
\hline 統合能力 & $\begin{array}{l}\text { ·効果的なCRMの } \\
\text { 実施には, チャネル, } \\
\text { 摌, 顧客, および } \\
\text { 従業員の調整が必要 } \\
\text { である。 }\end{array}$ & & $\begin{array}{l}\text { ·組織の分権化が不 } \\
\text { 十分であり, 柔軟に } \\
\text { 適応できない。 }\end{array}$ & & $\begin{array}{l}\text { - 必要とされる全社 } \\
\text { 的関与を過小評価す } \\
\text { る。 }\end{array}$ & $\begin{array}{l}\text { · CRMに適合する } \\
\text { ようう組織を変革する } \\
\text { 前に導入する。 }\end{array}$ & 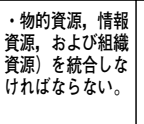 & - 機能の境界 & $\begin{array}{l}\text { ·機能間の統合 } \\
\text { ·組織全体のコミッ } \\
\text { トメント } \\
\text { · CRMの考え方と } \\
\text {-致する報酬構造 }\end{array}$ \\
\hline $\begin{array}{l}\text { オペレーショ } \\
\text { ン能カ }\end{array}$ & 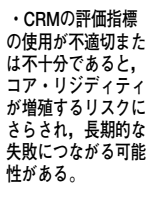 & 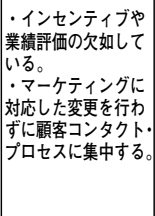 & 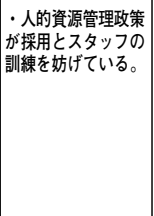 & $\begin{array}{l}\text { ・ビジネス・プロ } \\
\text { セスに柔軟性がな } \\
\text { い。 }\end{array}$ & 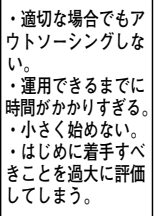 & $\begin{array}{l}\text { ·顧客戦略を作り出 } \\
\text { す前にCRMM実施 } \\
\text { する。 } \\
\text { ・CRM技術は多い } \\
\text { 方が良いと考える。 } \\
\end{array}$ & & ・ スキルの欠如 & $\begin{array}{l}\text { ·顧客データの所有 } \\
\text { 権の特定化 } \\
\text { ·CRM訓練·専 } \\
\text { 門スキルの開発 } \\
\text { ·適切なな業績評価指 } \\
\text { 標 } \\
\text { ·適切な資金的関与 }\end{array}$ \\
\hline 分析能力 & & & & $\begin{array}{l}\text { ・データ分析を過 } \\
\text { 小諳価する。 }\end{array}$ & $\begin{array}{l}\text { ・データを集めず, } \\
\text { 手持ちデータも方利用 } \\
\text { しない。 } \\
\text { ·検証しない。 }\end{array}$ & & & $\begin{array}{l}\text { ·貧弱なデータ } \\
\text { の質と量 } \\
\text { 不適切な尺度 } \\
\text { シスムム }\end{array}$ & $\begin{array}{l}\cdot \text { CRMの訓練·専 } \\
\text { 門スキルの開発 } \\
\text { :豊富なデータの質 } \\
\text { と量 }\end{array}$ \\
\hline
\end{tabular}


のような関係を目指すのか, それに従って組織 をどのように変革するのかについて，トップ・ マネジメントによる十分な理解と支援が不可欠 である (Kale 2004; Davids 1999; Ryals and Payne 2001; Zablah, Bellenger, and Johnston 2004）。学習・市場志向能力においては，顧客 志向や長期志向, 競争への対応が重要であり, 顧客中心のビジョンを欠いていたり，技術主導 であったりしてはならない (Boulding et al. 2004; Kale 2004; Davids 1999; Zablah, Bellenger, and Johnston 2004)。統合能力で は，チャネル，技術，顧客，および従業員の調 整や物的資源, 情報資源, 組織資源の統合, そ して経営機能の統合が重要である（Boulding et al. 2004; Raman, Wittmann, and Rauseo 2006; Ryals and Payne 2001; Zablah, Bellenger, and Johnston 2004)。オペレーシ ヨン能力については, CRM の知識とスキル, CRM に適切な人的資源の配分や業績評価が必 要とされる（Boulding et al. 2004; Day 2000; Dibb and Meadow 2004; Davids 1999; Ryals and Payne 2001; Zablah, Bellenger, and Johnston 2004）。そして分析能力では，デー 夕の量や質に問題があったり，その分析スキル を欠いたりすることが問題となる（Kale 2004; Davids 1999; Ryals and Payne 2001; Zablah, Bellenger, and Johnston 2004)。

\section{4 顧客関係の市場マネジメント と組織マネジメント}

以上の分析から，これまで明確にされてこ なかった CRM の 2 つの局面を指摘すること ができる（図ー3参照）。第一の局面は顧客関 係の市場マネジメントと呼びうるものであり,
図-3

CRM の 2 つの局面

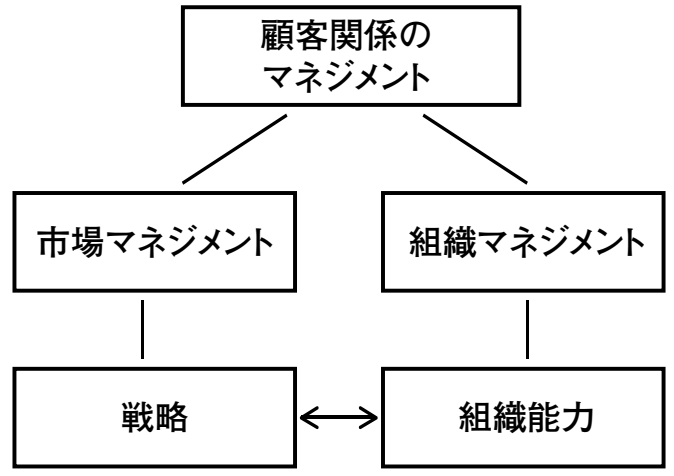

CRM 研究の系譜において中心的なテーマであ った。そこでは顧客関係プロセスを通じて優 良な顧客との長期的な関係を構築・維持し， その関係をいかにマネジメントするかが課題 となる。方向づけ能力とオペレーション能力 は，この局面において遂行される $\mathrm{CRM}$ 能力 である。第二は顧客関係の組織マネジメント というべき局面であり, 組織プロセスを通じ て顧客関係の市場マネジメントを作動させる 組織の能力に関わる。そこでは組織における 市場・学習志向能力, 統合能力, 分析能力を いかに効果的に遂行するかが課題となる。

$\mathrm{CRM}$ が高い成果を生み出すには，CRM 戦 略という市場マネジメントの局面に注目する だけでは十分ではない。CRM の成功・失敗要 因が組織能力に関連することからも明らかな ように，優れた CRM 戦略を構築・遂行する 優れた組織能力にも注意しなければならない。 CRM の成否は，いかに優れた CRM 戦略を実 行するかという顧客関係の市場マネジメント に加えて，いかに優れた CRM 能力を構築す るかという組織マネジメントに依存している のである。 


\section{謝辞}

この研究は, 平成 18 年度文部科学省科学研究 費基盤（C）「サービス産業における CRM 戦 略の実証的研究」（筆者を代表研究者とする小 樽商科大学大学院商学研究科松尾睦教授との 共同研究）の一部である。

注

1) http://www.sbbit.jp/article/art.asp?newsid $=5269 \&$ ref=rss

\section{参考文献}

Barnes, Bradley R., Martin T. Fox, and D. S. Morris (2004) , “Exploring the Linking between Internal Marketing, Relationship Marketing and Service Quality: a Case Study of a Consulting Organization," Total Quality Management, Vol.15, No.5-6, pp.593601.

Boulding, William, Richard Staelin, Michael Ehret, and Wesley J. Johnston （2005）, “A Customer Relationship Management Roadmap: What Is Known, Potential Pitfalls, and Where to Go," Journal of Marketing, Vol.64, No.4, pp.155-166.

Buttle, Francis (2003) , Customer Relationship Management: Concepts and Tools, Elsevier Butterworth Heinemann, Oxford.

Crossan, M. M., H. W. Lane, and R. E. White (1999), “An Organizational Learning Framework: From Intuition to Institution," Academy of Management Review, Vol.24, No.3, pp.522-537.

Davids, Meryl (1999) , "How to Avoid the 10 Biggest Mistakes in CRM," Journal of Business Strategy, Vol.20, No.6, pp.22-26.

Day, George S. (1994) , “The Capabilities of MarketDriven Organizations,” Journal of Marketing, Vol.58, No.4, pp.37-52

- (2000) , "Managing Market Relationship," Journal of the Academy of Marketing Science, Vol.28, No.1, pp.24-30.

- (2003) , “Creating a Superior Customer-Relating Capabilities,” Sloan Management Review, Vol.44, No.3, pp.77-82.

and Christophe Van den Bulte (2002) , “Superiority in Customer Relationship Management: Consequences for Competitive Advantage and Performance," Marketing Science Institute, Cambridge, MA.
Dibb, Sally and Maureen Meadows (2004) , “Relationship Marketing and CRM: A Financial Service Case Study," Journal of Strategic Marketing, Vol.12, No.2, pp.111-125.

Dickie, Jim (2005), “Does CRM = Sales Effectiveness or Sales Ineffectiveness?, http://crmguru.custhelp.com/cgibin/crmguru.cfg/php/enduser/std_adp.php?p_faqid=1250

Dodge, H. Robert and Sam Fullerton (1997) , “From Exchange to Relationships: A Reconceptualization of the Marketing Paradigm, Journal of Marketing Theory \& Practice, Vol.5, No.2, pp.1-7.

Grant, Robert M. (1991) , “The Resource-Based Theory of Competitive Advantage: Implications for Strategy Formulation," California Management Review, Vol.33, No.3, pp.114-133.

Greenberg, Paul (2001) , CRM at the Speed of Light: Capturing and Keeping Customers in Internet Real Time, Osborne.

Grönroos, Christian (1994), “From Marketing Mix to Relationship Marketing: Towards a Paradigm Shift in Marketing," Management Decision, Vol.32, No.2, pp.4-20.

Hobby, John (1999), "Looking After the One Who Matters,” Accountancy Age, (October 28) , pp.2830

Huber, George (1991) , “Organizational Learning: The Contributing Process and Literatures, Organization Science, Vol.2, No.1, pp.88-115.

Hunt, Shelby D. (1997) , “Competing through Relationships: Grounding Relationship Marketing in ResourceAdvantage Theory," Journal of Marketing Management, Vol.13, No.5, pp.431-445.

Kale, Sudhir (2004) , "CRM Failure and the Seven Deadly Sins,” Marketing Management, Vol.13, No.5, pp.42-46.

Knox, Simon, Stan Maklan, Adrian Payne, Joe Peppard, and Lynette Ryals (2003), Customer Relationship Management: Perspectives from the Market Place, London, Butterworth-Heimemann.

Kohli, Ajay K. and Bernard J. Jaworski (1990) , “Market Orientation: The Construct, Research, Propositions, and Managerial Implications," Journal of Marketing, Vol. 54, No.2, pp.1-18.

Kotler, Philip and Gary Armstrong (2007) , Principles of Marketing, 12th edition, Prentice Hall College Division.

Mahoney, J.T. and J.R.Pandian （1992），“The Resourcebased View within the Conversation of Strategic Man- 
agement," Strategic Management Journal, Vol.13, No.5, pp.363-380.

Miner, Ann S. and Stephen J. Mezias (1996) , “Ugly Ducking No More: Pasts and Futures of Organizational Learning Research,” Organization Science, Vol.7, No.1, pp.88-99.

Mithas, Sunil, M.S. Krishnan, and Claes Fornell (2005) , "Why Do Customer Relationship Management Applications Affect Customer Satisfaction?" Journal of Marketing, Vol.69, No.4, pp.201-209.

Nevis, Edwin C., Anthony J. DiBella, and Janet M. Gould (1995) , "Understanding Organization as Learning System,” Sloan Management Review, Vol.36, No.2, pp.73-85.

O’Malley, Lisa and Darryn Mitussis (2002) , “Relationships and Technology: Strategic Implications," Journal of Strategic Marketing, Vol.10, No.3, pp.225-238.

Payne, Adrian (2006) , Handbook of CRM: Achieving Excellence in Customer Management, ButterworthHeinemann, Oxford.

and Pennie Frow (2005) , “A Strategic Framework for Customer Relationship Management," Journal of Marketing, Vol.69, No.4, 167-176.

_ and Jagdish N. Sheth (2001) , “Customer Relationship Management: Emerging Practice, Process, and Discipline," Journal of Economic and Social Research, Vol.3, No.2, pp.1-34.

Peppers, Don, Martha Rogers, and Bob Dorf （1999）, "Is Your Company Ready for One-to-One Marketing?” Harvard Business Review, Vol.77, No.1, pp.101-109.

Plakoyiannaki, Emmanuella and Nikolaos Tzokas (2002) , "Customer Relationship Management: A Capabilities Portofolio Perspective," Journal of Database Marketing, Vol.9, No.3, pp.228-237.

Raman, Pushkala, C. Michael Wittmann, and Nancy Rauseo (2006) , "Leveraging CRM for Sales: The Role of Organizational Capabilities in Successful CRM Implementation," Journal of Personal Selling \& Sales Management, Vol.26, No.1, pp.39-53.

Reinartz, Werner, Manfred Krafft, and Wayne D. Hoyer (2004) , “The Customer Relationship Management Process: Its Measurement and Impact on Performance," Journal of Marketing Research, Vol. 41, No.3, pp.293305.

Rigby, Darrell K., Frederick F. Reichheld, and Phil Schefter (2002) , “Avoid the Four Perils of CRM," Harvard Business Review, Vol. 80, No.2, pp.101-104.

Ryals, Lynette (2005) , “Making Customer Relationship
Management Work: The Measurement and Profitable Management of Customer Relationships," Journal of Marketing, Vol.69, No.4, pp.252-261.

— Issues in the Implementation of Relationship Marketing through Customer Relationship Management,” European Management Journal, Vol. 19, No.5, pp.534-542.

— and Adrian Payne (2001) , “Customer Relationship Management in Financial Services: Towards Information-enabled relationship Marketing," Journal of Strategic Marketing, Vol.9, No.1, pp.3-27.

Shath, Denish, Ronald T. Rust, A Parasuraman, Richard Staelin, and George S. Day (2006) , “The Path to Customer Centricity," Journal of Service Research, Vol.9, No.2, pp.113-124.

Sheth, Jagdish. N. and A. Parvatiyar (1995a), "Relationship Marketing in Consumer Marketplace: Antecedents and Consequences," Journal of the Academy of Marketing Science, Vol.23, No.4, pp.255-271.

and A. Parvatiyar (1995b) , "The Evolution of Relationship Marketing," International Business Review, Vol.4, No.4, pp.397-418.

, Rajendra S. Sisodia, and Arun Sharma (2000), "The Antecedents and Consequences of CustomerCentric Marketing," Journal of the Academy of Marketing Science, Vol.28, No.1, pp.55-66.

Shoemaker, Mary E. (2001) , “A Framework for Examining IT-Enabled Market Relationships,” Journal of Personal Selling \& Sales Management, Vol.21, No.2, pp.177-185.

Sisodia, Rajendra S. and David B. Wolfe (2000), "Information Technology: Its Role in Maintaining and Enhancing Relationships," in J. N. Sheth and A. Parvatiyar (eds.), Handbook of Relationship Marketing, Sage Publishers, pp.525-563.

Srivastava, Rajendra K., Tasadduq A. Shervani, and Liam Fahey (1999) , “Marketing, Business Processes, and Shareholder Value: An Organizationally Embedded View of Marketing Activities and the Discipline of Marketing," Journal of Marketing, Vol.63, No.4, pp.168-179.

Srinivasan, Raji and Christine Moorman (2005), "Strategic Firm Commitments and Rewards for Customer Relationship Management in Online Retailing," Journal of Marketing, Vol. 69, No.4, pp.193-200.

Verhoef, Peter C. (2003) , “Understanding the Effect of Customer Relationship Management Efforts on Customer Retention and Customer Share Development," 
Journal of Marketing, Vol.67, No.4, pp.30-45.

Yim, Frederick Hong-kit, Rolph E. Anderson, and Srinivasan Swaminathan (2004), “Customer Relationship Management: Its Dimensions and Effect on Customer Outcomes," Journal of Personal Selling \& Sales Management, Vol.24, No.4, pp.263-278.

Zablah, Alex R., Danny N. Bellenger, and Wesley J. Johnston (2004) , “Customer Relationship Management Implementation Gaps,” Journal of Personal Selling \& Sales Management, Vol. 24, No.4, pp.279-275.

Zeithaml, Valerie A, Ronald T. Rust, Katherine N. Lemon (2001) , “The Customer Pyramid: Creating and Serving Profitable Customers," California Management Review, Vol.43, No.4, pp.118-142.

Zikmund, William G., Raymond McLeod, and Faye W. Gilbert (2003) , Customer Relationship Management, Wiley.

南 知惠子 (2005), 『リレーションシップ・マーケテ イング』千倉書房。
(2006)，『顧客リレーションシップ戦略』千 倉書房。

近藤 公彦（こんどうきみひこ）

同志社大学商学部卒業 (1984)。

神戸大学大学院経営学研究科博士後期課程単位取得 (1990)。

岡山商科大学商学部助手, 専任講師, 助教授, 小樽 商科大学商学部助教授, 教授を経て, 現在, 同大学 院商学研究科アントレプレナーシップ専攻（専門職 大学院）教授。

米国ノースウェスタン大学大学院 IMC 学科客員教 授 $(2005 \sim 2006)$ 。

専攻は, マーケティング論および流通システム論。 